\title{
IMPROVING STUDENTS' VOCABULARY MASTERY THROUGH TEAM GAME TOURNAMENT TECHNIQUE IN RECOUNT TEXT
}

\author{
Alfanny Putri Hidayat ${ }^{1}$, Mohammad Septian Fauzi \\ ${ }^{1}$ IKIP Siliwangi \\ ${ }^{2}$ IKIP Siliwangi \\ ${ }^{1}$ alfanny.putri26@gmail.com, ${ }^{2}$ zhiiecraze@gmail.com
}

\begin{abstract}
This research focuses on the effect of recount text to improve vocabulary mastery through Team Game Tournament (TGT) .The methotology which is used by using action research.The subjects are the grade I students of SMA PASUNDAN 3 Cimahi.Two classes, science class and social class were taken the subject of observation. This research object is to find the effect and extent of recount genre to improve students' ability in vocabulary mastery where the population and sample is taken from grade I students of SMA PASUNDAN 3 Cimahi.After the data been collected, the researcher find out that the students in the grade I has improve in their vocabulary. It has been also caused by quiz through Team Game Tournamentc(TGT) practice of recount text, that recount text can be applied to improve the vocabulary mastery skill of the students.
\end{abstract}

Keywords: Vocabulary, Team Games Tournaments, Collaborative Learning, Discovery Learning

\section{INTRODUCTION}

Vocabulary is the key for students to understand what they hear and read; and to communicate successfully with others. The main purpose of learning a foreign language is to be able to communicate in English, therefore mastering vocabulary is not only important, but also important in a foreign language environment. Murcia (2001: 285) as cited in Parmawati (2018) states that vocabulary learning is central to language acquisition, whether the language is first, second, or foreign. A number of studies have shown that vocabulary size in children is a strong predictor of success in later classes. The greater the vocabulary of children in the elementary class, the greater their academic achievement in the upper class Coxhead as cited in (Antonacci \& O'Callaghan, 2012) . Rowenhorst (2006: 3) in (Target, 2006) adding vocabulary, or word meaning, is one of the keys to understanding. Based on the expert opinion above, the researcher say that vocabulary greatly influences students' academic performance. So it is important to build a large stock of vocabulary so that communication is successful. Teaching vocabulary, especially in junior high school is not easy. Teachers must pay more attention because if they take the wrong steps that lead to reluctance in the learning process, this can affect students' willingness to learn English. Often, teachers give students the vocabulary they need but fail to teach them how to access the vocabulary and make it their own words (Preszler (2006: 2) in (Elvilla, Laili, Fardhani, \& Santihastuti, 2014).

As we know that compulsory subjects are first in junior high school. When students feel the teacher is teaching English, this indirectly gets their motivation and makes them want to learn more. Conversely, when teaching methods make them bored, they will be reluctant to learn more. As Nguyen Thi Thanh Huyen (2002) states that for many English language students as a 
foreign language, vocabulary learning is considered boring, because they have to memorize foreign words and they are asked to complete many exercises. This situation makes it difficult for students to memorize the vocabulary taught. Krashen as cited in (Latifi, Ketabi, \& Mohammadi, 2013) believes that to fully use language in communicative settings, second language or students must first acquire language before learning is introduced. In other words, we must make the learning process fun in the first step in language learning. It can prevent stress and also create a pleasant atmosphere in the classroom. To create a pleasant atmosphere, researchers plan to implement the Game Tournament Team (TGT) Technique in teaching vocabulary. stated that Slavin had found TGT to improve basic skills, student achievement, positive interactions between students, mainstream acceptance of classmates and self-esteem. From acknowledging that, the researcher consider TGT to be suitable for asking for vocabulary.

Many experts say that Team Game Tournaments are very easy to implement and also fun and challenging. Team Game Tournaments are techniques that require students to study in groups with 4-5 heterogeneous abilities and then ask them to work with their team to ensure that all team members have arranged agreed lessons. The main idea behind TGT is to motivate students to encourage and help each other with the skills provided by the teacher. The technique chosen because it promises to provide opportunities for students to be actively involved in the teaching and learning process. They have the opportunity to discuss the difficulties the words they face with their group members that make the learning process successful. Therefore, the researcher decided to use this technique because researchers wanted to find out whether this technique was "truly" effective or not to understand the vocabulary. And then, the researcher also using recount text to know the development of enriching their vocabularies. Anderson (1997: 49) as cited in (Language \& Program, 2013) suggests that recount is a text which tells about events happening in the past in a sequence of time. The purpose of the text is to tell the audience about what happened in the past and when it happened. It can be considered recount texts can function to inform and to tell stories of past events. This kind of texts where they share with others can also add references for them to read which also improving the vocabulary mastery. The purpose of this study was to determine whether or not the influence of the use of Team Games Tournament (TGT) Technique or not on vocabulary mastery of 10th grade SMA PASUNDAN 3 cimahi students in 2019.

\section{METHOD}

Employing a quasi experimental with pretest-posttest design, this study examined the effect of using Team Games Tournament (TGT) Technique on vocabulary mastery. A quantitative research was held. In this design, two classes with the same average score selected as the experimental group and controls group. The experimental group approved with their approval was the Game Tournament Technique Team, while the control group answered the vocabulary using the Lecture Technique as a normal process in school.

The model of pre-test and post-test design is as follow:

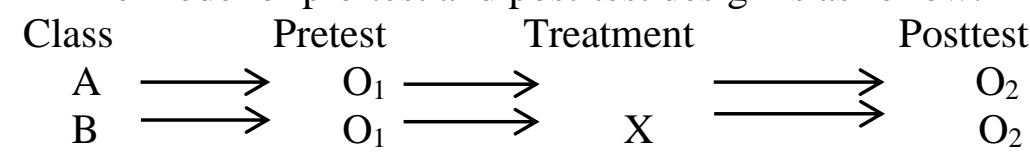

Key:
A: Control class
B: Experimental class
$\mathrm{O}_{1:}$ Pre-test
$\mathrm{O}_{2}$ : Post-test 
X: Treatment (McMillan \& Schumacher, 2001: 342) as cited in (E. M. Bitzer, 2013)

\section{RESULTS AND DISCUSSION}

\section{Results}

In this research, the researcher conducted research at SMA PASUNDAN 3 Cimahi. There are IPS 1 as experimental class and MIPA 2 as control class. The researcher used the vocabulary test to get the data of the students vocabulary mastery. This test is divided in two parts, pre-test and post-test. After conducting pre-test, the researcher give them a treatment, it aims for increasing their ability in vocabulary mastery. The researcher give a treatment Team Game Tornament (TGT) technique. The researcher give them a quiz as treatment to find out the progress of students in their vocabulary mastery about Recount text in the pre-test and posttest. The experimental class was taught vocabulary by using Team Game Tournament in teaching learning process.

Based on academic, the tenth grade in SMA Pasundan 3 Cimahi were never taught using TGT technique to enrich their vocabulary. The teacher only taught the vocabulary by using Lecturing technique. The respondent of this research were the tenth grade in SMA Pasundan 3 Cimahi.

1. Analysis of Pretest

\section{a. Test of Normality}

\begin{tabular}{|c|c|c|c|c|c|c|c|}
\hline \multicolumn{8}{|c|}{ Tests of Normality } \\
\hline & \multirow[b]{3}{*}{ metode } & \multicolumn{3}{|c|}{ Kolmogorov-Smirnov $^{\mathrm{a}}$} & \multicolumn{3}{|c|}{ Shapiro-Wilk } \\
\hline & & Statisti & & & atisti & & \\
\hline & & $\mathrm{c}$ & $\mathrm{df}$ & Sig. & $\mathrm{c}$ & $\mathrm{df}$ & Sig. \\
\hline $\begin{array}{l}\text { postt } \\
\text { est_s }\end{array}$ & $\begin{array}{l}\text { kelas } \\
\text { eksperimen }\end{array}$ & ,138 & 31 & , 139 & ,930 & 31 & ,043 \\
\hline iswa & kelas kontrol & , 149 & 31 & ,078 & ,886 & 31 & ,003 \\
\hline
\end{tabular}

The above table shows that the significance value of control class was 0.078. Meanwhile, the significance value of experimental class was 0,139 . These value were higher than 0.05 . it means both of the data were normally distributed.

\section{b. Mann-Whitney Test}

\begin{tabular}{llrr}
\hline \multicolumn{3}{c}{ Test Statistics $^{\mathbf{a}}$} \\
\hline \\
\hline & & pretest_siswa \\
\hline Mann-Whitney U & 176,000 \\
\hline Wilcoxon W & & 672,000 \\
\hline$Z$ & & $-4,301$ \\
\hline Asymp. Sig. (2-tailed) & Sig. &, 000 \\
\hline $\begin{array}{lllr}\text { Monte Carlo Sig. (2- } \\
\text { tailed) }\end{array}$ & $\begin{array}{l}\text { 95\% Confidence } \\
\text { Interval }\end{array}$ & $\begin{array}{l}\text { Lower } \\
\text { Bound }\end{array}$ &, $000^{\mathrm{b}}$ \\
\cline { 2 - 4 } & & Upper &, 000 \\
& & Bound &, 000 \\
\hline & Sig. &, $000^{\mathrm{b}}$ \\
\hline
\end{tabular}




\begin{tabular}{llll}
\hline $\begin{array}{l}\text { Monte Carlo Sig. (1- } \\
\text { tailed) }\end{array}$ & $\begin{array}{l}\text { 95\% Confidence } \\
\text { Interval }\end{array}$ & $\begin{array}{l}\text { Lower } \\
\text { Bound }\end{array}$ &, 000 \\
\cline { 2 - 3 } & $\begin{array}{l}\text { Upper } \\
\text { Bound }\end{array}$ &, 000 \\
\hline a. Grouping Variable: metode & \\
\hline b. Based on 10000 sampled tables with starting seed 2000000. \\
\hline
\end{tabular}

The table above shows that Mann Whitney was higher than 0,05. It means that $\mathrm{H}_{\mathrm{o}}$ was accepted. It can be concluded that the significant both of the data there is no significant different between using Team Games Tournaments (TGT) as collaborative learning and discovery learning in learning teaching vocabulary in recount text.

\section{Analysis of Posttest}

\begin{tabular}{llrrrr}
\hline & & \multicolumn{3}{c}{ Kolmogorov-Smirnov } \\
\cline { 3 - 5 } & Metode & Statistic & df & \multicolumn{1}{c}{ Sig. } \\
\hline \multirow{2}{*}{ posttest_siswa } & kelas eksperimen &, 138 & 31 &, 139 \\
\cline { 2 - 5 } & kelas kontrol &, 149 & 31 &, 078 \\
\hline
\end{tabular}

The above table shows that the significance value of control class was 0.078. Meanwhile, the significance value of experimental class was 0,139 . These value were higher than 0.05 . it means both of the data were normally distributed.

Test of Homogeneity of Variance

\begin{tabular}{ll|l|r|r|r} 
& & $\begin{array}{c}\text { Levene } \\
\text { Statistic }\end{array}$ & df1 & df2 & \multicolumn{1}{c}{ Sig. } \\
\hline posttest_siswa & Based on Mean & 5,681 & 1 & 60 &, 020 \\
\cline { 2 - 6 } & Based on Median & 5,679 & 1 & 60 &, 020 \\
\cline { 2 - 6 } & $\begin{array}{l}\text { Based on Median and } \\
\text { with adjusted df }\end{array}$ & 5,679 & 1 & 56,544 &, 021 \\
\cline { 2 - 6 } & Based on trimmed mean & 5,607 & 1 & 60 &, 021 \\
\hline
\end{tabular}

Based on the table above shows that the data were not homogeny and the variances of the two classes were equal because sig. of experimental class and control class lower than 0,05 .

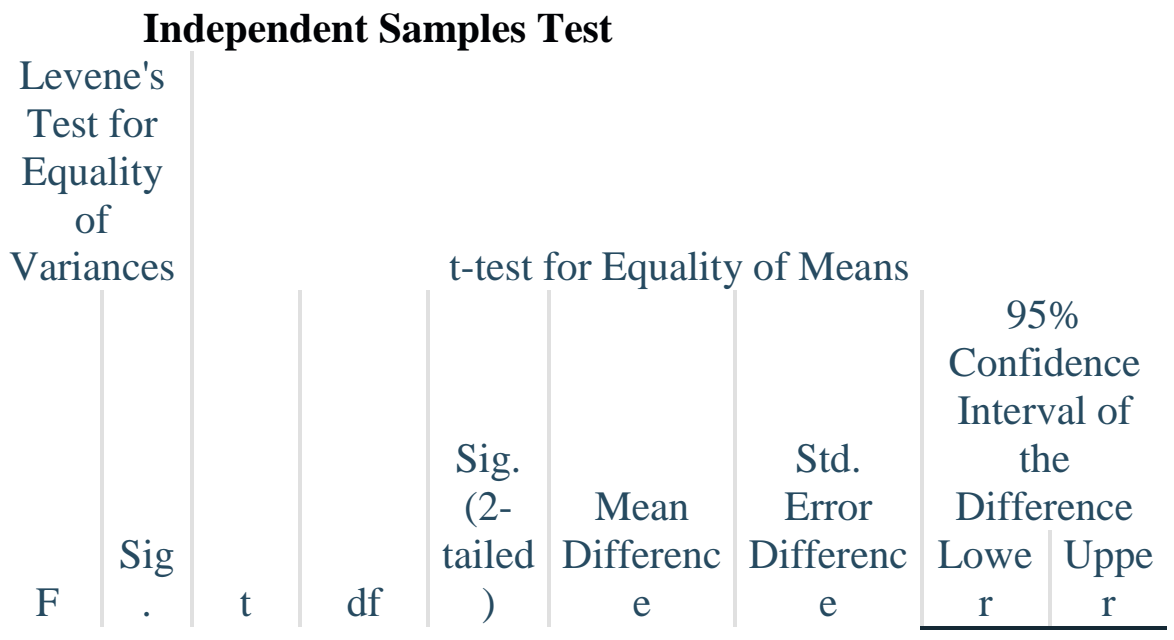




\begin{tabular}{|c|c|c|c|c|c|c|c|c|c|c|}
\hline \multirow[t]{2}{*}{$\begin{array}{l}\text { posttest_sis } \\
\text { wa }\end{array}$} & $\begin{array}{l}\text { Equal } \\
\text { variance } \\
\text { s } \\
\text { assume } \\
\text { d }\end{array}$ & $\begin{array}{r}5,68 \\
1\end{array}$ & $\begin{array}{r}, 02 \\
0\end{array}$ & $\begin{array}{r}- \\
3,66 \\
5\end{array}$ & 60 & ,001 & $-13,129$ & 3,582 & $\begin{array}{r}- \\
20,29 \\
5\end{array}$ & $5,963^{-}$ \\
\hline & $\begin{array}{l}\text { Equal } \\
\text { variance } \\
\text { s not } \\
\text { assume } \\
\text { d }\end{array}$ & & & $\begin{array}{r}- \\
3,66 \\
5\end{array}$ & $\begin{array}{r}52,65 \\
9\end{array}$ & ,001 & $-13,129$ & 3,582 & $\begin{array}{r}- \\
20,31 \\
5\end{array}$ & 5,943 \\
\hline
\end{tabular}

Based on the table above the (sig.) 2 tailed was 0,001 , the data was more lower than 0,005 . It means $\mathrm{H}_{0}: \mu 1 \neq \mu 2$ ( $\mathrm{H}_{0}$ rejected). It means that, there are significant different between pretest score of experimental class which used TGT and control class which used lecturing technique

\section{CONCLUSION}

Based on the result, from the analysis pretest and posttest, it can be conclude that there is significant different between students who were taught by using TGT and those who were taught lecturing technique. It shows that using TGT can enrich the student vocabulary mastery. TGT can encourages students' motivation to study, increasing students' confidence, and also the students can solve their problem together with their friend. This method also can develop a sense of cooperation and mutual respect between students in their group members. Therefore, the students become more active and interested in the class because there is activity in the form of tournament game in this model. But in TGT takess a long time, because the teacher must establish condition prescribed in the application of TGT. The teacher is required to be good at choosing the subject matter suitable for this method. And also the teacher must prepare before it applied, for example, to create some questions for tournaments or competitions. And the teacher must give their a reward as a gift that they participated to follow the tournaments.

\section{ACKNOWLEDGMENTS}

Alhadulillahi rabil alamin, the researcher expresses his highest gratitude to Allahsubhanahu wa ta'ala for blessing, love, opportunity, health, and mercy to complete this journal entitled "Improving Students' Vocabulary Mastery Through Team Games Tournament Technique in Recount Text" is submitted as the final requirement in accomplishing undergraduate degree at English education, IKIP Siliwangi Bandung. In arranging this thesis, a lot of people have provided motivation, advice and support for the researcher. In this valuable chance, the researcher intended to express her gratitude and appreciation to all of them. First, the researcher's deepest appreciation goes to her beloved parents for the endless love, pray, support and remind me t keep going and never giving up.

The researcher presents her sincere apreciation goes to her first advisor Dr. Irma Savitri Sadikin, M.Pd., and her second advisor Trisnendri Syahrizal, M.Hum for their advice on arranging this journal and support me to never give up.

\section{REFERENCES}


Antonacci, P. A., \& O'callaghan, C. M. (2012). Essential Strategies For Teaching Vocabulary. Promoting Literacy Development, 83-114.

E. M. Bitzer. (2013). Exploring Student Teachers' Active Learning Through Self-Assessment, Peer Assessment And Reflection At Rundu Campus Of The University Of Namibia. 01(01), 53-65.

Elvilla, A., Laili, N., Fardhani, A. E., \& Santihastuti, A. (2014). The Effect Of Using Team Games Tournament (Tgt) Technique On Vocabulary Mastery Of The Eighth Grade Students At Smpn 13 Jember In The 2013/2014 Academic Year.

Language, E., \& Program, T. (2013). Student Of English Language Teaching Program Of Fbs State University Of Padang Graduated On September 20132 Advisor, Lecturer In Faculty Of Languages And Arts, State University Of Padang. Jelt, (September).

Latifi, M., Ketabi, S., \& Mohammadi, E. (2013). The Comprehension Hypothesis Today: An Interview With Stephen Krashen. Electronic Journal Of Foreign Language Teaching, 10(2), 221-233.

Nguyen Thi Thanh Huyen, K. T. T. N. (2002). Learning Vocabulary Through Games: The Effectiveness Of Learning Vocabulary Through Games. Asian Efl Journal.

Parmawati, A. Using Magic Sentences Technique To Improve Students'vocabulary (Classroom Action Research In The First Semester Students Of Ikip Siliwangi Bandung).

Target, O. (2006). On Target : Strategies To Build Student Vocabularies Grade4-12. 